\title{
The Financial Crisis Early-Warning Research of Real Estate Listed Corporation Basted Logistic Model
}

\author{
RongJin.Li ${ }^{1}$, TingGao ${ }^{2}$ \\ BeiLin District YanTa Road No. 13. Xi'an,China \\ Email:447387407@qq.com
}

Keywords: Real Estate Listed Corporation, Financial Crisis, Early-warning Mod

\begin{abstract}
The establishment of the financial crisis warning system is convenient for the listing Corporation to find the signal of financial crisis, and then improve the ability of the listing corporation to resist risks. In this paper, we take the real estate listed companies as the research object. Through screening and optimization, we choose asset-liability ratio and other four indicators (from the initial 26 financial indicators that could reflect the overall financial condition of listed real estate companies) to build logistic financial crisis early-warning models. The results of sample group reflect that there are $75 \%$ accuracy and 25\% misjudgment rate in 2013; The results of prediction group reflect that there are $80.2 \%$ accuracy in 2013. We could predict that the effect is more ideal. For the real listed corporation, they could build early-warning model of financial crisis to avoid financial risks.
\end{abstract}

\section{Introduction}

For the real estate industry, on the one hand, it has partial nature of the financial industry, it requires higher demand for funds, long period of investment, meanwhile the asset-liability ratio of real estate listed corporation is generally higher than $80 \%$, while the debt could bring the good effect of financial leverage, a higher debt will also bring more financial risks, even the financial crisis ; On the other hand, as the pillar of the national economy, the real estate industry's health and stability plays a vital role. Therefore, it is necessary for real estate listed corporation to explore the financial crisis early-warning research basted logistic model. At present, the domestic research on financial crisis warning is not very perfect, but due to the development of foreign securities market is relatively mature, the corresponding financial crisis early-warning research is also relatively perfect, it has formed a variety of financial crisis warning system. Under the help of the existing research results, in this paper, the Logistic regression method was used to build financial crisis early-warning model of real estate industry, hoping to improve the prediction accuracy, provide an effective financial crisis early-warning tool.

\section{The cause Analysis Of The Financial Risk Of Real Estate Listing Corporation}

There are many factors which influencing financial risks of the real estate listed company. In external factors, macroeconomic environment, resources environment, law and policy environment, industry cycle and other external factors may cause financial risk, and even bring financial crisis, meanwhile, the impact of these "external factors" will eventually be reflected through the financial data.

In Internal factors, many real estate listed corporation's capital structure is irrational, it shows the phenomenon of the financial leverage's excessive use and higher asset liability ratio , and this is the main reason why real estate listed corporation format financial risk. Meanwhile, the short-term debt repayment pressure and higher financial costs are easy to make the enterprise blindly do some diversified investment to spread risk. However these diversified investments will take up a lot of capital under the new industry, and it will ignore the development of the main business so that the main business profit levels appear serious decline. 


\section{Construction Of The Financial Crisis Early-Warning Model of Real Estate Listed Corporation}

\subsection{Sample selection and data sources}

The range of sample is real estate listed companies selected from Shanghai stock exchange and the Shenzhen stock exchange with sample matching method. Selection criteria: firstly the paper choose 4 ST companies which possess complete financial data, and then choose 4 non ST companies which total asset size is not more than $10 \%$ compared with 4 ST companies. There are 8 samples in this paper. As shown in table 1

Table 1 Samples

\begin{tabular}{c|l|l|c}
\hline \multicolumn{2}{c|}{ ST companies } & \multicolumn{2}{c}{ Non ST matching company } \\
\hline SHENZHENINTERNATIONAL Co.,Ltd & 000056 & 000150 & YIHUA HEALTHCARE CO.,LTD \\
\hline GUO XING Co.,Ltd & 000838 & 000797 & WUYI OF CHINA Co.,Ltd \\
\hline TIANRUN Co.,Ltd & 002113 & 002077 & DA GANG Co.,Ltd \\
\hline QIANFENG Co.,Ltd & 600733 & 600736 & $\begin{array}{c}\text { TECHNOLOGY OF SUZHOU } \\
\text { Co.,Ltd }\end{array}$ \\
\hline
\end{tabular}

The purpose of building model is to find the signs of the financial deterioration in the first 2 to 3 years before the financial crisis, and then take the corresponding remedial measures to avoid further deterioration. Therefore, this paper choose the first three years of special treatment as forecast year, namely from 2011 to 2013,

\subsection{Construction Of The Index System About Financial Crisis Early-Warning Model}

\subsubsection{The preliminary establishment of index system}

It is difficult to use a few simple index to reflect the occurrence of financial crisis, at the same time, we lack some relevant theories to guide, so it is difficult to select some relevant index. In the process of constructing the index system, with the characteristics of real estate industry and the basic principles of "comprehensive and quantitative", this paper mainly extract the 26 alternative indicators from five aspects, like the enterprise's solvency, operation ability, profit ability and development ability and the cash flow ability. As shown in Table 2. 
Table 2. Primary index variables

\begin{tabular}{|c|c|c|}
\hline & The Index Name & Index \\
\hline \multirow{6}{*}{ Solvency } & Current ratio & $\mathrm{X}_{1}$ \\
\hline & Quick ratio & $\mathrm{X}_{2}$ \\
\hline & Cash ratio & $\mathrm{X}_{3}$ \\
\hline & Asset-liability ratio & $\mathrm{X}_{4}$ \\
\hline & Equity ratio ; & $\mathrm{X}_{5}$ \\
\hline & Current assets ratio & $\mathrm{X}_{6}$ \\
\hline \multirow{5}{*}{ Operation Ability } & Total asset turnover & $\mathrm{X}_{7}$ \\
\hline & Inventory turnover & $\mathrm{X}_{8}$ \\
\hline & Accounts receivable turnover & $\mathrm{X}_{9}$ \\
\hline & Current assets turnover & $\mathrm{X}_{10}$ \\
\hline & Fixed asset turnover & $\mathrm{X}_{11}$ \\
\hline \multirow{4}{*}{ Profit Ability } & Total assets net profit margin & $\mathrm{X}_{12}$ \\
\hline & Sales net interest rates & $\mathrm{X}_{13}$ \\
\hline & The cost profit margins & $\mathrm{X}_{14}$ \\
\hline & Return on equity & $\mathrm{X}_{15}$ \\
\hline \multirow{5}{*}{ Development Ability } & Net profit growth rate & $\mathrm{X}_{16}$ \\
\hline & Operating profit growth & $\mathrm{X}_{17}$ \\
\hline & Capital preservation increment rate & $\mathrm{X}_{18}$ \\
\hline & Growth rate of total assets & $\mathrm{X}_{19}$ \\
\hline & Capital accumulation & $X_{20}$ \\
\hline \multirow{6}{*}{ Cash Flow Ability } & Net cash net content & $X_{21}$ \\
\hline & Cash net operating income levels & $\mathrm{X}_{22}$ \\
\hline & Operating profit cash net content & $X_{23}$ \\
\hline & Operating index & $\mathrm{X}_{24}$ \\
\hline & Cash than current liabilities & $\mathrm{X}_{25}$ \\
\hline & Cash debt ratio & $\mathrm{X}_{26}$ \\
\hline
\end{tabular}

\subsubsection{Index selection of Logistic Financial Crisis Early-warning model}

1) The Text of K-S

Before building a early-warning model of financial affairs, the index variables shall be selected through the test of significance to find out some variables as the judging index for the model, which indicating significant difference between financially distressed company and normal company But before the test, it is necessary to judge that whether the values of sample index conform to normal distribution or not via K-S test so as to determine whether the significance analysis on values of sample index can be examined by T test. The results of test K-S is shown in the following Table 3. According to the probability of $\mathrm{P}$ which is automatically calculated from SPSS test, it can be noticed that most of probabilities of $\mathrm{P}$ of sample index variables are more than the significance level 0.05 except $X_{8}$ and $X_{21}$. Therefore we can conclude that the null hypothesis: the samples conform to normal distribution and the $\mathrm{T}$ test can be used to find financial index having significant differences between financially distressed company and normal company. 
Table 3 The Text of K-S

\begin{tabular}{c|c|c|c|c|c|c|c|c}
\hline & $\mathrm{X}_{1}$ & $\mathrm{X}_{2}$ & $\mathrm{X}_{3}$ & $\mathrm{X}_{4}$ & $\mathrm{X}_{5}$ & $\mathrm{X}_{6}$ & $\mathrm{X}_{7}$ & $\mathrm{X}_{9}$ \\
\hline Kolmogorov-SmirnovZ & .895 & .418 & .853 & .643 & .928 & .667 & .513 & 1.447 \\
& .400 & .995 & .460 & .803 & .355 & .765 & .955 & .053 \\
\hline \multirow{2}{*}{ Kolmogorov-SmirnovZ } & $\mathrm{X}_{10}$ & $\mathrm{X}_{11}$ & $\mathrm{X}_{12}$ & $\mathrm{X}_{13}$ & $\mathrm{X}_{14}$ & $\mathrm{X}_{15}$ & $\mathrm{X}_{16}$ & $\mathrm{X}_{17}$ \\
& .472 & .663 & .897 & 1.159 & .870 & 1.416 & .905 & .652 \\
& .979 & .772 & .397 & .136 & .436 & .056 & .386 & .789 \\
\hline Kolmogorov-SmirnovZ & $\mathrm{X}_{10}$ & $\mathrm{X}_{11}$ & $\mathrm{X}_{12}$ & $\mathrm{X}_{13}$ & $\mathrm{X}_{14}$ & $\mathrm{X}_{15}$ & $\mathrm{X}_{16}$ & $\mathrm{X}_{17}$ \\
& 1.344 & .596 & 1.344 & 1.136 & .939 & .587 & .465 & .607 \\
\hline
\end{tabular}

2) The Text of $\mathrm{T}$

The index variables following the normal distribution the normal distribution, like X1 to X7 ,X9 to X20, X21 to X26, were selected, and these data were matched and tested by T-text. As for two groups' data of every variables, choosing descriptive statistics like average value and standard deviation between 2011 to 2013. Comparing the difference of the average value in two groups index variables between ST companies and non-ST companies, whether they have significant different and choosing the index having significant financial crisis to contribute next model. The null hypothesis of this test H0: there is no significantly different between financial crisis companies and normal companies. The significance level is 0.05 . The result can be seen from the T-text of matching sample, the significance level of X4,X7,X11 to X15,X18,X23,X25 and X26 was lower than 0.05 , so the index variables of the financial crisis companies and normal companies were different significantly. The index which were tested by $\mathrm{T}$ and had significant financial crisis will be selected by next index.

Table 4 The T-text of matching sample

\begin{tabular}{|c|c|c|c|c|c|}
\hline \multirow{3}{*}{ Variable } & \multicolumn{3}{|c|}{ Difference In Pairs } & \multirow[t]{3}{*}{$\mathrm{t}$} & \multirow[t]{3}{*}{ Sig. } \\
\hline & \multirow[t]{2}{*}{ Mean Value } & \multicolumn{2}{|c|}{ The Difference of the 95\% Confidence Interval } & & \\
\hline & & Lower Limit & Upper Llimit & & \\
\hline $\mathrm{X} 1$ & -.791316083 & -2.489899699 & .907267532 & -1.025 & .327 \\
\hline $\mathrm{X} 2$ & -.003358333 & -.338814592 & 332097925 & -.022 & .983 \\
\hline X3 & .077320667 & -.168128767 & .322770100 & .693 & .502 \\
\hline $\mathrm{X} 4$ & .059767667 & -.201584753 & .321120086 & .403 & .045 \\
\hline $\mathrm{X} 5$ & 913659083 & -6.132278256 & 7.959596423 & .285 & .781 \\
\hline $\mathrm{X} 6$ & -.003791167 & -.157565460 & .149983126 & -.054 & .958 \\
\hline $\mathrm{X7}$ & -.161363750 & -.309671824 & -.013055676 & -2.395 & .036 \\
\hline X9 & 3336.295739000 & -3921.608070358 & 10594.199548358 & 1.012 & .333 \\
\hline $\mathrm{X} 10$ & -.118693500 & -.291332755 & .053945755 & -1.513 & .158 \\
\hline X11 & -1.063195917 & -14.307717075 & 12.181325242 & -.177 & .063 \\
\hline $\mathrm{X} 12$ & -.12594500 & -.25467684 & .00278684 & -2.153 & .044 \\
\hline $\mathrm{X} 13$ & -7.287147083 & -14.759580599 & 185286432 & -2.146 & .045 \\
\hline X14 & -.747950250 & -1.261922389 & -.233978111 & -3.203 & .008 \\
\hline $\mathrm{X} 15$ & 2.937584333 & -4.001064960 & 9.876233627 & .932 & .031 \\
\hline $\mathrm{X} 16$ & -4.023139333 & -22.091375356 & 14.045096690 & -.490 & .634 \\
\hline $\mathrm{X} 17$ & 3.348462417 & -7.219376589 & 13.916301423 & .697 & .500 \\
\hline X18 & .559597417 & -1.328630396 & 2.447825230 & .652 & .048 \\
\hline X19 & -.153664583 & -.456392954 & 149063787 & -1.117 & .288 \\
\hline $\mathrm{X} 20$ & .559597417 & -1.328630396 & 2.447825230 & .652 & .528 \\
\hline X22 & 32.789857833 & -30.113286310 & 95.693001976 & 1.147 & .276 \\
\hline $\mathrm{X} 23$ & 7.388700083 & -1.796137300 & 16.573537467 & 1.771 & .037 \\
\hline X24 & 3.940427636 & -2.025913049 & 9.906768322 & 1.472 & .172 \\
\hline X25 & 132291500 & -.124821744 & .389404744 & 1.132 & .022 \\
\hline X26 & .048288083 & -.135236220 & 231812387 & .579 & .045 \\
\hline
\end{tabular}


3) Correlation analysis

There is a linear correlation the initial index. Therefore, this paper makes a simple correlation analysis among the above selected financial indicators. As shown in Table 5

Table 5 Correlation Test

\begin{tabular}{l|c|c|c|c|c|c|c|c|c|c|c}
\hline & $\mathrm{X}_{4}$ & $\mathrm{X}_{7}$ & $\mathrm{X}_{11}$ & $\mathrm{X}_{12}$ & $\mathrm{X}_{13}$ & $\mathrm{X}_{14}$ & $\mathrm{X}_{15}$ & $\mathrm{X}_{18}$ & $\mathrm{X}_{23}$ & $\mathrm{X}_{25}$ & $\mathrm{X}_{26}$ \\
\hline $\mathrm{X}_{4}$ & 1 & -.07 & -.72 & $-.438^{*}$ & -.227 & $-.427^{*}$ & .385 & -.166 & -.030 & .019 & -.213 \\
$\mathrm{X}_{7}$ & -.069 & 1 & .791 & .034 & $.515^{*}$ & $.437^{*}$ & -.27 & .028 & -.068 & .369 & .329 \\
$\mathrm{X}_{11}$ & -.72 & .791 & 1 & .287 & .343 & $.469^{*}$ & -.172 & -.094 & $.455^{*}$ & .243 & .357 \\
$\mathrm{X}_{12}$ & $-.438^{*}$ & .034 & .287 & 1 & .132 & $.10^{*}$ & -.16 & .201 & .003 & -.010 & .043 \\
$\mathrm{X}_{13}$ & -.227 & $.15^{*}$ & .343 & .132 & 1 & $.752^{* *}$ & -.28 & .126 & -.059 & .701 & $.501^{*}$ \\
$\mathrm{X}_{14}$ & $-.427^{*}$ & $.437^{*}$ & $.469^{*}$ & $.10^{*}$ & $.752^{* *}$ & 1 & -0.9 & .176 & -.013 & .118 & .296 \\
$\mathrm{X}_{15}$ & .385 & -.27 & -.172 & -.157 & -.281 & -0.89 & 1 & -.240 & .017 & -.208 & -.373 \\
$\mathrm{X}_{18}$ & -.166 & .028 & -.09 & .201 & .126 & .176 & -.24 & 1 & -.264 & .174 & .160 \\
$\mathrm{X}_{23}$ & -.030 & -.07 & $.455^{*}$ & .003 & -.059 & -.013 & .017 & -.264 & 1 & .330 & .370 \\
$\mathrm{X}_{25}$ & .019 & .369 & .243 & -.010 & .701 & .118 & -.21 & .174 & .330 & 1 & $.875^{* *}$ \\
$\mathrm{X}_{26}$ & -.213 & .329 & .357 & .043 & $.501^{*}$ & .296 & -.37 & .160 & .370 & $.875^{* *}$ & 1 \\
\hline
\end{tabular}

In this correlation analysis, variable correlation coefficient as high as 0.72 between $\mathrm{X}_{11}$ and $\mathrm{X}_{4}$, at the same time variable correlation coefficient as high as 0.791 between $\mathrm{X}_{11}$ and $\mathrm{X}_{7}$,we can conclude that $\mathrm{X}_{11}, \mathrm{X}_{4}$, and $\mathrm{X}_{7}$ were highly correlated and eliminate $\mathrm{X}_{11}$; correlation coefficient between $\mathrm{X}_{14}$ and $\mathrm{X}_{15}$ is 0.89 , which is highly correlated, and then further analyze the relationship between two variables and the rest, according to smaller the principle of index correlation ,we exclude $\mathrm{X}_{14}$. In the same way, we exclude $\mathrm{X}_{12} 、 \mathrm{X}_{15} 、 \mathrm{X}_{25}$ and $\mathrm{X}_{2}$.

After processing, the correlation of $X_{4} 、 X_{7} 、 X_{13} 、 X_{18}$ and $X_{2}$ is weak, therefore this article use these five variables to build Logistic model.

\subsection{Logistic Financial Crisis Early-warning Model}

In the Logistic Regression Early-warning Model, there are two explained variables respectively set as 0 and 1 . " 0 " represents the company did not have a financial crisis, and " 1 " represents a financial crisis. $\mathrm{P}$ is used to represent the probability of financial crisis facing listed real estate company, and this paper adopt the ultimately determined five indicators to establish the Logistic Regression Early-warning Model. The function of probability:

$$
p=\frac{e^{\alpha+\beta_{1} x_{1}+\beta_{2} x_{2}+\cdots+\beta_{m} x_{m}}}{1+e^{\alpha+\beta_{1} x_{1}+\beta_{2} x_{2}+\cdots \beta_{m} x_{m}}}
$$

Input data of the 5 variables mentioned above from estimated sample composed of 4 companies with financial crisis and 4 normal companies into SPSS statistical software, and conduct regression analysis by Logistic regression procedures of SPSS statistical software.

Through the comprehensive inspection on the model coefficients, we can see that the chi-square value of this early-warning model is 33.271 , and the probability is 0 , much less than the significance level of 0.05 . Reject null hypothesis, namely the linear relation between each independent variable and $\mathrm{P}$ is very significant and it's reasonable to adopt this model; The "negative 2 times log likelihood "of this early-warning model is very much small, demonstrating the high degree of fitting of this model. At the same time, Nagelkerker2 value of 0.857 is close to 1 , which reflects the explanation degree of the equation on explained variable deviation, the closer it's to the 1 , the higher the fitting degree of the equation is. So the regression early-warning model is :

$$
p=\frac{e^{10.588-1.469 x_{4}-8.899 x_{7}+2.014 x_{13}-7.905 x_{18}-5.417 x_{23}}}{1+e^{10.588-1.469 x_{4}-8.899 x_{7}+2.014 x_{13}-7.905 x_{18}-5.417 x_{23}}}
$$




\section{The Validity Test Of Logistic Financial Crisis Early-warning Model}

There are 8 research samples, the financial crisis companies and financial normal companies are each 4 , the ratio is 1 to 1 . In the financial forewarning model, when it appear this situation that "ST companies being mistaken for the ST companies", or "the ST companies being mistaken for ST", we take 0.5 as Critical value of financial crisis probability. If $\mathrm{P}$ is greater than 0.5 , the sample is the financial crisis enterprise, and vice versa

\subsection{The text of sample group}

This paper put the sample company's financial data in 2013, 2012 into the model to determine the accuracy of the forewarning model. Prediction results are shown in Table 7 and Table 8.

Table 7 Sample group classification results- 1 years before the financial crisis(2013)

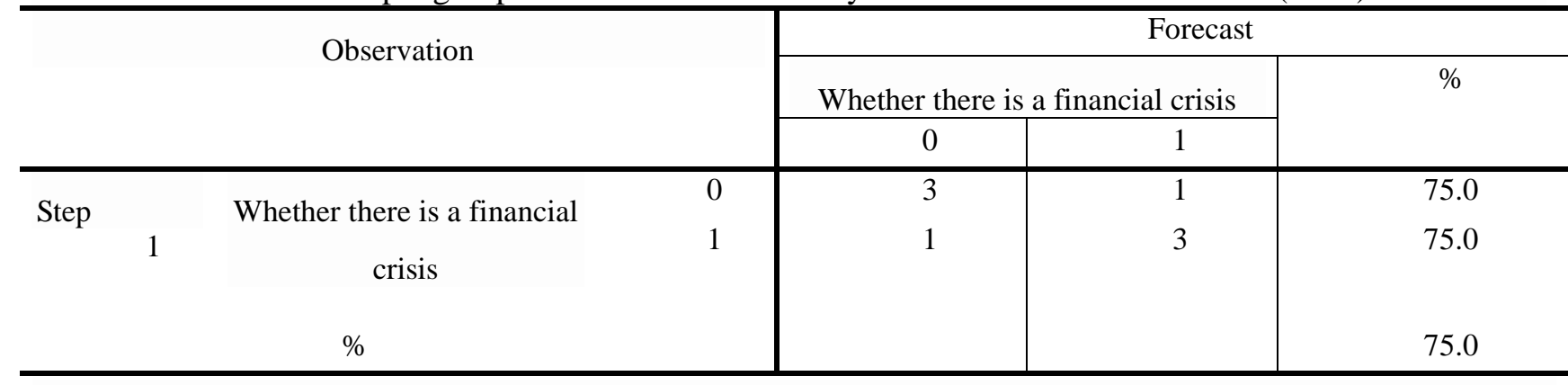

Table 8 Sample group classification results- 2 years before the financial crisis(2012)

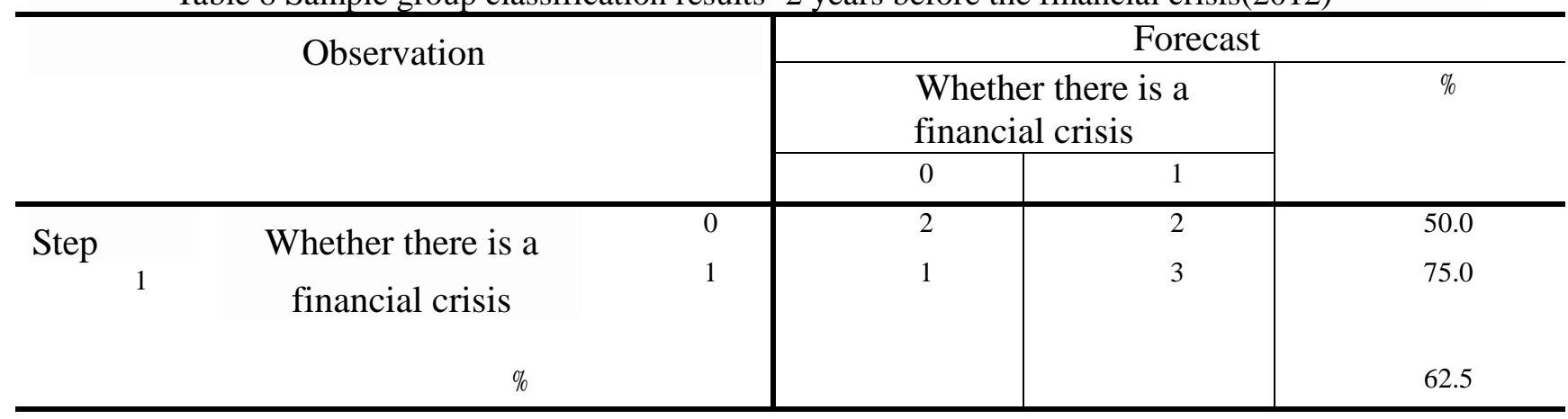

From the model judging results of sample group of 1 year before its financial crisis, we can see that among the 4 normal companies, 1 company has been mistaken for ST company, with 75\% accuracy and 25\% misjudgment rate; among the 4 ST companies, 1 company has been mistaken for non-ST company with $75 \%$ accuracy, the predictive effect being somewhat ideal. However, the predictive accuracy of 2 years before the crisis is lower than that of 1 year before the crisis. The judging accuracy of 2 years before the crisis for ST company is relatively high, being $75 \%$. It can be found that as time passed, the financial risk is becoming greater, and the financial situation is getting worse. The closer it's towards the year which produces financial risk, the more accuracy which the Financial Crisis Early-Warning Model has.

\subsection{The text of prediction group}

To further test the predictive ability and applicability of the Financial Crisis Early-Warning Model, it is necessary to extract a prediction group and predict the financial situation of the group. Adopt "random sampling method" to select prediction group. As to the selected 35 healthy sample firms, conduct statistical calculations by the financial data of 2011 , and then make predictions on whether the financial crisis will occur in 2012 or not; in order to expand the selection range and quantity of prediction group of ST company, select 20 companies listed under special treatment respectively in year 2011, year 2010, year 2009, year 2008 and year 2007, conduct statistical calculations by the financial data of 1 year before the ST to determine whether it's be set with a financial crisis. The random decimation ratio between health companies and companies with 
financial crisis is 1 to 0.571 . The judging results of the Early-Warning Model are shown in Table9. Table 9. The classification results of prediction group

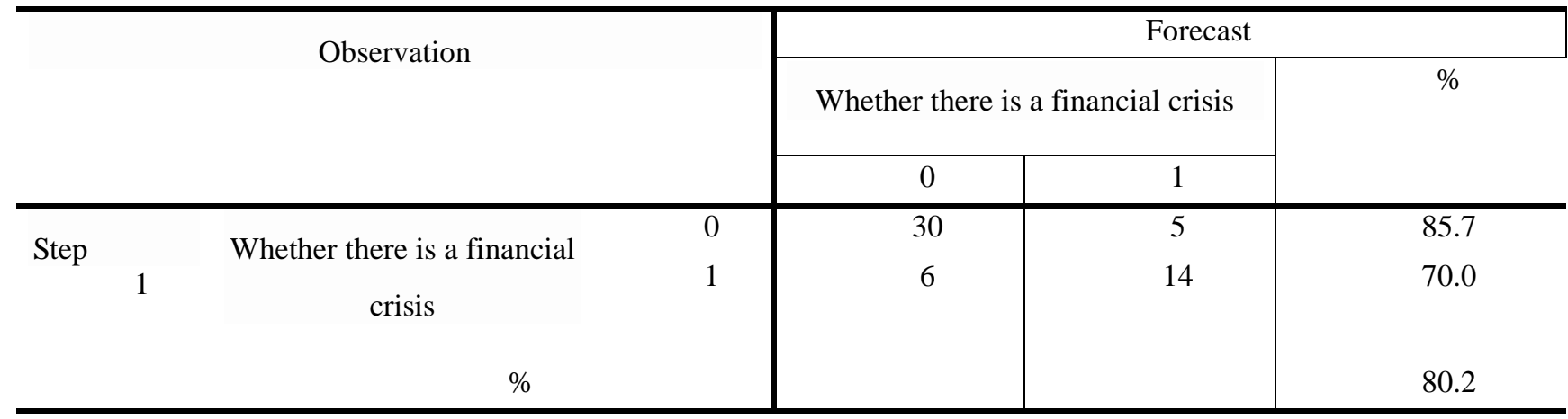

From the model judging results of prediction group, we can see that among the 4 normal companies 5 company has been mistaken for ST company, with 85.7\% accuracy and 14.3\% misjudgment rate; among the 4 ST companies, 6 company has been mistaken for non-ST company with $70 \%$ accuracy and 30\% misjudgment rate. In general, prediction accuracy of Financial Crisis Early-warning Model is $80.2 \%$, it has a high credibility for real estate listed corporation and this will help the management of the company's financial system.

\section{Conclusion}

This paper takes real estate listed companies as the research object, establishes Logistic Financial Crisis Early-warning Model, and carries on inspection. The results show that: the results of financial crisis early-warning model basically conform to the actual situation. Its forecast accuracy of financial crisis is $80.2 \%$, so this model has good forecast ability. After conducting K-S test, T test and correlation test on the initial 26 financial indicators, it's ultimately determined to take five financial variables including asset liability ratio $\mathrm{X}_{4}$, total assets turnover $\mathrm{X}_{7}$, sales net profit ratio $\mathrm{X}_{13}$, hedging and proliferating ratios $\mathrm{X}_{18}$ and operating profit cash net value $\mathrm{X}_{23}$ as independent variables of Logistic model. These five financial indicators can better reflect the financial situation of real estate listed companies. From the evaluation results of the model, we can see that when cut value is 0.5 , the accuracy of Logistic model predicting the totality reaches $80.2 \%$, for non-ST companies, its forecast accuracy is $85.7 \%$, and for ST companies with financial crisis, its forecast accuracy is $70 \%$. The regression results of the model show that, by this Logistic Model we can effectively predict the financial crisis of real estate listed companies to effectively establish risk early-warning mechanism, and guarantee the competitive advantage of the enterprise.

\section{Acknowledgement}

Funded project in shaanxi province department of education

Corresponding author,Ting Gao,15249247539,447387407@qq.com

\section{Reference}

[1] . Qin.He. Real Estate Listed Corporation Financial Crisis Early-Warning Research Basted Logistic Model. Accounting communication [J].2010 (9): 88:90.

[2]MeiYan. Cheng, Jie Cheng. The Establishment and Application of the Financial Risk Early-warning Model of real estate listed Corporation in China. [J].Journal of wuhan university of technology, 2013 (6): 151-156.

[3]Ping Tao,ChangQingShen, YeHui.Sun . Study onFinancialRisk Identification and Disposal of real estate listed Corporation[J]. Journal of Engineering Management, 2010 (1): 107-112. 
[4] RongYan.Zhang,AiWen.Zhang,SiSi.Hhuang. real estate listed Corporation 's Financial Early-warning based on cash flow .[J]. Finance and Accounting Monthly,2012.9: 67:71.

[5]LingZhi.Shen. Study on the FinancialCrisis Early- warning System of the Listed Corporation.[D]. East China Normal University.2007.

[6]LiLi. Real Estate Listed Corporation Financial Crisis Early-Warning Research Basted Logistic Model. [J]. Productivity Research,2014(1):32-36

[7] Huddart. Employee Stock Options[J]. Journal ofAccounting and Economics, 1994, 18（2): 207-212.

[8] Jensen, Meckling. From to Enterprise Risk[J]. Government Finance Review. 2005, 2（21): $56-62$

[9] Gupta. Huefner. Assessing the Vulnerability to Failure ofAmerican Industrial Firms: a Logistic Analysis[J]. Journal of Business Finance and Accounting, 1985，2: 19-45

[10]. Fitzpartrick, P. J.. A Comparison of Ratios of SuccessfulIndustrial Enterprises With those Failed Firms. The AccountantsPublishing Company, 1932

[11] Beaver, William H.. Financial Ratios as Predictors of Fail-ure. Journal of Accounting Research, 1966; 4

[12] Blum M.. Failing company discriminant analysis. Journal ofAccounting Research, 1974; 12. 